Portland State University

PDXScholar

Communication Faculty Publications and

Presentations

Communication

2012

\title{
Local Political Knowledge and Assessments of Citizen Competence
}

Lee Shaker

Portland State University, Ishaker@pdx.edu

Follow this and additional works at: https://pdxscholar.library.pdx.edu/comm_fac

Part of the Communication Commons, and the Political Theory Commons

Let us know how access to this document benefits you.

\section{Citation Details}

Published as: Shaker, L. (2012). Local political knowledge and assessments of citizen competence. Public Opinion Quarterly, 76(3), 525-537.

This Post-Print is brought to you for free and open access. It has been accepted for inclusion in Communication Faculty Publications and Presentations by an authorized administrator of PDXScholar. Please contact us if we can make this document more accessible: pdxscholar@pdx.edu. 
Local Political Knowledge and Citizen Competence 2749 Words

\begin{abstract}
This article contrasts the national and local political knowledge of a random sample of 1001 Philadelphians with the aim of enhancing the scholarly understanding of citizen competence. Empirical study of citizen competence extends back more than 50 years, but the survey data that have been brought to bear upon the topic are almost exclusively focused on national-level politics. Consequently, sweeping conclusions about the competence of the American public have often been grounded in a fairly narrow empirical trench. The comparison in this article depicts a slew of differences in the distribution of knowledge across national and local politics, many of which challenge established notions of who is politically knowledgeable. This, in turn, has implications for which members of society are seen as politically competent and how competent the public as a whole is thought to be.

Lee Shaker, Portland State University

Support for this study was provided by Michael X. Delli Carpini and the Annenberg School for Communication, University of Pennsylvania. In addition, the author wishes to thank Eran N. Ben Porath and Martin Gilens for their time and contributions.
\end{abstract}


2 Local Political Knowledge and Citizen Competence 
For decades, scholars have drawn a dark picture of the American public's understanding of political affairs (Converse 1964; Delli Carpini and Keeter 1996; Somin 1998, 2004). Doing so raises fundamental questions about the citizenry's ability to effectively contribute to its governance. Yet, even though citizens are not as informed as they could be, American democracy functions. The study of citizen competence grapples with this paradox: How can a government be legitimately of the people if the people barely know the political basics?

Scholars offer an array of responses. Democracy functions because citizens follow elite cues, are only responsible for making narrowly constrained choices, and form a coherent mass in the aggregate (Page and Shapiro 1992; Popkin 1993; Sniderman et al. 1991). Though the direct reward (a more informed vote) for accumulating political knowledge is small, enough citizens seek political information (for various reasons) to form a basis for governance (Somin 2006).

Modern empirical attempts to address the citizen competence controversy extend back more than 50 years, but the survey data that have been brought to bear upon the topic are almost exclusively focused on national-level politics. ${ }^{1}$ A smattering of cross-national comparisons of national-level data exist, but there are limits to what may be generalized about a complex matter - citizen competence - from data that largely relate to one political context. There are two compelling reasons to include local political affairs in the study of citizen competence. First, any understanding of competence that does not include local matters is incomplete. To put it starkly, $96 \%$ of all political contests in the United States are for local offices (Macedo and Karpowitz

\footnotetext{
${ }^{1}$ The primary exception to this appraisal is Delli Carpini and Keeter's (1996) overarching assessment of political knowledge, in which state and local political knowledge are briefly described.
} 
2006). Second, including local affairs offers the possibility of identifying political competence that is not apparent (or does not exist) at the national level.

Thoroughly studying local politics is difficult because of the variability of local contexts and the generalizability issues that stem from such differences, but it is a worthwhile pursuit nonetheless. To address this empirical lacuna, this article offers a case study that contrasts the national and local political knowledge of a single population: a random sample of the residents of Philadelphia. The results suggest that the citizens who are knowledgeable about national and local matters differ, and this has implications for assessments of the public's political competence.

\section{Citizen Competence and Political Knowledge}

The prior research most pertinent to this article investigates the level and distribution of political knowledge throughout the American populace (Delli Carpini and Keeter 1996;

Neumann 1986). Three relevant conclusions can be drawn from this line of work: (1) the level of political knowledge throughout the American public is not high, (2) there are some instances and circumstances in which the public is informed, (3) if any Americans appear more knowledgeable, and thus politically competent, they are likely white, wealthy, educated, men who are middle-aged. Though it should be noted that knowledge is not competence in and of itself (Bennett 1997); Lupia 2006), the established view is that a low level of knowledge is indicative of political incompetence (Somin 1998, 2004; Bennett 1988, 1996). ${ }^{2}$ So, one

\footnotetext{
${ }^{2}$ The argument that the measurement of knowledge levels with survey items is a poor proxy for evaluating citizen competence (Weissberg 2001) is compelling, but not entirely relevant to this article. Survey-based political knowledge scales are not complete and total representations of competence. But, the limitations of such scales are
} 
interpretation of prior political knowledge research is that many, if not most, citizens are not politically competent and that this is especially true of women, minorities, and those with lower socioeconomic status.

Skepticism about widespread citizen competence peaks in research that identifies a group of citizens termed "know-nothings" which responds to political queries correctly less than onethird of the time (Hyman and Sheatsley 1947). Estimates place the size of this group at roughly one-third of the population and are based on questions about national politics (Bennett 1988; Somin 1998). It is suggested that these know-nothings "are not mentally prepared to continue the society because they basically do not understand the society enough to value it...People who do not value what they have rarely keep it for long" (Stein 1983, p.19 in Bennett 1988, p. 489). Drawing this conclusion solely on the basis of national-level measurements, however, is premature and may be misleading.

Though limited in depth, literature focused on local political knowledge hints at the possibility that many citizens who possess little national political knowledge may be more focused on local affairs. In several disparate studies, women were more likely to know the name of the person in charge of their local schools (Verba, Burns, and Schlozman 1997). Bobo and Gilliam (1990) find black citizens to be more knowledgeable when they have a black mayor. Similarly, Delli Carpini and Keeter (1996) found that black citizens in Richmond, VA had higher levels of local knowledge than white citizens (but lower levels of national knowledge) even

constant across political contexts. Consequently, the raison d'être of this article - to evaluate the implications of differences observed in the comparison of citizens' knowledge of local and national politics - is not mooted by these weaknesses. 
without the presence of a black mayor. Additionally, they find that gender was not a significant predictor of local knowledge in their examination of Richmond. These results were echoed in a more recent study of Seattle that found no difference in local knowledge across gender but a significant advantage for non-white respondents (Moy et al. 2004). Age, income, and education appear to have a positive bearing upon both local and national knowledge - though the relationships may be weaker at the local level (Shaker 2009). Still, empirically speaking, the notion that political competence may mean qualitatively different things for people throughout the population is given short shrift and the (sometimes implicit) assertion that competence centers upon national politics is clear (Lupia 2006).

The issue public hypothesis is one approach to evaluating citizen competence that does consider the varied ways in which citizens actually engage with politics (Krosnick 1990; Price and Zaller 1993). This hypothesis suggests that, though the general level of political knowledge throughout society is low, certain segments of the population are attuned to - and knowledgeable about - specific policy matters. So, rather than requiring individuals to be generally competent (Converse 1964), able to aptly employ shortcuts (Lupia 1994), or collectively stable (Page and Shapiro 1992), the issue public hypothesis posits a fourth way to conceptualize citizen competence: specialization.

The notion of specialization dovetails with Luskin's (1990) assertion that competence (or "sophistication") arises from a combination of opportunity, ability, and motivation. Just as certain citizens may have the right combination of opportunity, ability, and motivation to be knowledgeable about an issue like agricultural subsidies, others may be knowledgeable about local affairs. Because both the hurdles to and benefits of competence vary across national and 
7 Local Political Knowledge and Citizen Competence

local political matters, it follows that the population of sophisticates will differ across the contexts.

$\underline{\text { Data and Method }}$

The analyses in this article use a single dataset that contains the results from a telephone survey of 993 Philadelphians administered by SRBI of New York City. The survey was conducted from November 7-21, 2007 in the wake of a mayoral election in Philadelphia. The response rate, defined by the American Association for Public Opinion Research (AAPOR) as RR4, was $21.6 \%$ and reflects refusals as well as non-contacts. Table 1 provides unweighted sample descriptives from this survey as well as from the Philadelphia sample in the 2007 U.S. American Community Survey (ACS). ${ }^{3}$ For the analyses, my data were weighted with iterative proportional fitting to account for nonresponse among known subpopulations using the gender, age, race and education parameters from the ACS data. ${ }^{4}$

Citizens’ local and national political knowledge were probed with, respectively, 7 and 5 items adapted from prior research and designed to balance current events awareness with

\footnotetext{
${ }^{3}$ As is often the case, a large number of survey respondents (172) refused to provide or did not know their annual income. To examine whether or not their absence skewed the results presented here, the missing respondents were included in alternate analyses by imputing an income that equaled the mean income of other respondents in their Zip code. Conducting the analyses with these imputed values generated results that were very similar in substance to those reported here. Since the omission of the respondents with missing income values did not result in substantive differences in the findings, they were excluded.

${ }^{4}$ Every significant result reported below from the weighted analysis is present and significant if the same tests are conducted on the unweighted data. Income figures from the ACS are not used to weight the data because they are not sufficiently comparable to the income variable in the present survey.
} 
knowledge of political fundamentals (see full question wording in Appendix A). Multiple-choice options were not provided. ${ }^{5}$ Separate scales of local and national political knowledge are constructed by taking the mean of each respondent's answers ( 0 for an incorrect answer, 1 for a correct answer). Both scales range from 0 (low) to 1 (high) with strong reliability (national: Chronbach’s $\alpha=.74$; local: Chronbach’s $\alpha=.77$ ). On average, respondents scored slightly lower on the national political knowledge scale $(\mathrm{M}=.50, \mathrm{SD}=.30)$ than on the local political knowledge scale $(\mathrm{M}=.52, \mathrm{SD}=.29)$. There is a positive correlation $(\mathrm{r}=.59, \mathrm{p}<.01)$ between the two scales.

$\underline{\text { Results }}$

A pair of simple OLS regressions depict the relationships between basic demographic characteristics and political knowledge in Table 2. While all the expected relationships between the demographic variables and national political knowledge are confirmed, there is no significant difference across gender or between black and white respondents when predicting local political knowledge. The relationships between the remaining coefficients and the two dependant variables are similar across the two models, though the positive bearing of education is smaller at

\footnotetext{
${ }^{5}$ Recently, questions have been raised about the accuracy and quality of open-ended political knowledge items specifically in relation to the ANES surveys (Lupia and Krosnick). Open-ended responses were not recorded verbatim for this project and it is possible that some responses were counted as either correct or incorrect erroneously. A subset of interviews were monitored to ensure that the survey was administered properly and the results were recorded accurately. And, any inaccuracies driven by the survey method are equally likely to affect the national and local knowledge items. Accordingly, the results of the comparison between the two types of knowledge should maintain their integrity.
} 
the local level and the gap between white respondents and members of the 'other' category is larger at the national level. Overall, the local knowledge regression has somewhat less explanatory utility $\left(\mathrm{R}^{2}=.25\right)$ than the national knowledge regression $\left(\mathrm{R}^{2}=.37\right)$.

Figure 1A-B depicts the relationship between the two ordinal variables in the regressions above - education and income - and political knowledge. In both parts of the figure, the solid lines represent the actual observed percentage of correct national and local knowledge answers provided by respondents at the different educational and income levels. The dotted lines are the predicted percentages, derived from the linear regressions in Table 2.

In the education panel, the predicted and observed value lines for local and national political knowledge both cross between the third and fourth categories. Respondents with some post-secondary education and below know more about local politics than national politics, and the difference is significant (observed: $+4.8 \%, \mathrm{p}<.001$; predicted: $+4.7 \%, \mathrm{p}<.01$ ). ${ }^{6}$

Respondents who have at least a college degree know less about local politics than national politics; again, the difference is significant (observed: $-8.8 \%, \mathrm{p}<.001$; predicted: $-7.1 \%, \mathrm{p}<$ .05). For both domains, knowledge levels rise in lockstep with educational attainment.

In the income panel, the observed value lines cross between the third and fourth categories and the slope for local knowledge is negative between those categories. As with education, members of the lower income categories - those who reported incomes of less than $\$ 100,000$ - had significantly higher observed local knowledge than national knowledge (+3.1, p $<.01)$ and those with incomes over $\$ 100,000$ knew less about local affairs than national affairs (-

\footnotetext{
${ }^{6}$ The reported p-values in this section are for two-tailed t-tests.
} 
$12.8 \%, \mathrm{p}<.01)$. Controlling for the other demographic characteristics moots these differences: the predicted lines have virtually the same positive, consistent slope and local knowledge is slightly higher than national knowledge at every value.

\section{Citizen Competence and the Know-Nothings}

Strictly speaking, the established threshold for being a know-nothing is correctly responding to less than $1 / 3$ of the items in a political knowledge battery (Hyman and Sheatsley 1947; Bennett 1988). In the current sample, 39\% of respondents are local know-nothings and 38\% are national know-nothings. When knowledge of both domains is considered simultaneously, the proportion of know-nothings falls to $26 \%{ }^{7}$

Who are these know-nothings? Table 3 contains three logistic regressions that address this question. The first model predicts whether or not the respondents are local know-nothings. Notably, it shows that black respondents are significantly less likely to be know-nothings than white respondents and that there is no gender difference. In addition, older, wealthier, and more educated citizens are significantly less likely to be local know-nothings. The national knownothings are significantly more likely to be female, poorer, younger, less educated, and a minority. For the cumulative measure, there is no significant difference between black and white respondents or men and women.

\section{$\underline{\text { Discussion }}$}

\footnotetext{
${ }^{7}$ Two different approaches may be used to determine 'cumulative' know-nothings: cross-tabulating the local and national know-nothings or creating a new knowledge index that encompasses both domains. Either way, the percentage of know-nothings is stable at $26 \%$.
} 
The comparisons in this article clearly depict differences in the group-level distribution of local and national political knowledge in Philadelphia. These divergences, alone, shed some light on an understudied domain: local politics. In addition, the comparisons provide some leverage for evaluating two discrete, though related, points regarding the public's competence. The first is that scholars may have overlooked evidence that the public as a whole is generally more competent than believed by not including citizens' local political knowledge in their work. The second is that, even if the public as a whole is not more competent, evidence of specialization by citizens across contexts may indicate that certain groups of citizens are more competent than previously thought.

Altogether, the results show that Philadelphians might be seen as somewhat more competent as a whole when both local and national matters are considered simultaneously than when either is considered individually. The most compelling evidence in support of this perspective is that the number of know-nothings when both dimensions are combined is only about two-thirds as large as the number of know-nothings for either national or local matters alone. That said, on average the survey respondents only knew the correct answer to about half of both the local and national political knowledge items - undermining the notion that scholars have missed a hidden vein of high competence by disregarding local affairs.

But, the group-level differences in the Philadelphians who were knowledgeable about local and national politics have important implications for how scholars conceptualize competence as well as who they label as competent. To put it bluntly, assessments of competence, which often draw broad conclusions about the state of the American electorate based solely on national-level measurements, should be qualified as assessments of national 
political competence rather than citizen competence. And, the distributional differences in knowledge depicted here support Luskin's (1990) assertion that competence (or sophistication) is the product of a confluence of factors. Different citizens are knowledgeable about different matters based on relevance, accessibility, and aptitude. Even a lack of competence, as conceived of and measured by scholars, can be the result of rational decisions made by individuals. More energy should be expended in understanding the presence or absence of "competence" and less on quantifying it.

The scholarly perception of who is competent should be revised as well. After controlling for age, income, and education, neither black respondents nor women knew less about local politics than their white, male counterparts - though they were less knowledgeable about national politics. And, though there are links between education and both local and national knowledge, the evidence here suggests that those advantages are smaller at the local level than at the national level. The first conclusion that should be drawn here is simply that certain groups of citizens (at least in Philadelphia) are more attuned to local or national affairs - not that certain groups are inherently more competent than others. The second is that 'competent' itself is a value-laden term that implies inability rather than disinterest or dispossession. Returning to Luskin (1990), these results emphasize that competence arises from the nexus of ability, opportunity, and motivation and that the balance of these factors varies for local and national matters.

There are an array of limitations that should be considered in assessing this article. Most importantly, the findings of a single study - particularly a single-city, cross-sectional, case study - can add only so much to the understanding of political knowledge and citizen competence. It is possible that the results here may be unique to Philadelphia and not reflective of the conditions in 
other communities. Given the practical obstacles to simultaneously studying local politics in many cities in a quantitative fashion, however, a case study is the appropriate starting point. An obvious direction for future research is to continue this research to other cities.

A second methodological concern stands out: the results here may be, in some ways, dictated by the knowledge questions that were asked. The items were adapted from standard questions used by Delli Carpini and Keeter (1996) among others, but, at the local level, these questions have not been thoroughly tested for reliability and results may vary across cities due to the idiosyncrasies of each community. Many of the analyses depend on a comparison of local and national items - but the difficulty of the two kinds of questions cannot be held constant. Further, knowledge questions are only one, somewhat limited, approach to assessing competence. Still, knowledge questions are a widely accepted tactic for gaining some leverage on competence, and this article adds a one more wrinkle to an existing debate.

What contributions to our understanding of citizen competence does this article make? On average, the Philadelphians in this study were not omnicompetent or highly sophisticated. Yet, when both local and national political knowledge are assessed together, the picture that emerges is of many citizens following disparate topics, capable of contributing to their governance in different ways. In comparison to prior explorations of citizen competence focused upon national affairs, these results underline the notion that political competence has multiple dimensions. Ideally, in the future scholars will broaden both their conceptualization of citizen competence and their tactics in studying it accordingly. 


\section{Appendix A: Survey Items for Knowledge Scales}

\section{National Political Knowledge (\% correct response)}

1. Do you happen to know what job or political office is now held by Dick Cheney? (68\%)

2. Whose responsibility is it to determine if a law is constitutional or not? (34\%)

3. How much of a majority is required for the U.S. Senate and House of Representatives to override a presidential veto? (27\%)

4. Do you happen to know which party currently has the most members in the House of Representatives in Washington? (60\%)

5. Do you happen to know whether President Bush vetoed, or signed, a recent bill designed to increase spending for children's health insurance? (61\%)

\section{Local Political Knowledge (\% correct response)}

1. Do you happen to know what position Paul Vallas resigned from recently in Philadelphia? ${ }^{\mathrm{a}}$ $(41 \%)$

2. Do you know what position John Timoney held in Philadelphia? ${ }^{\mathrm{b}}$ (71\%)

3. Do you happen to know why John Street did not run again for mayor in this election? ${ }^{\mathrm{C}}$ (58\%)

4. Can you tell me which Democratic candidate for mayor advocated for a 'stop-and-frisk' gun policy during the primary campaign ${ }^{\mathrm{d}}(62 \%)$

5. Can you tell me which Democratic candidate for mayor used his own money to fund his primary campaign? ${ }^{\mathrm{e}}(14 \%)$

6. Can you tell me who the Republican candidate for mayor was this year? ${ }^{f}(35 \%)$

7. Can you tell me who won the general election for mayor? ${ }^{\mathrm{d}}(82 \%)$

${ }^{a}$ Paul Vallas was the CEO of School District of Philadelphia for 5 years before resigning in 2007. Vallas is white.

$\mathrm{b}$ John Timoney was the Chief of Police in Philadelphia from 1998-2001. Timoney is white.

c John Street was the mayor of Philadelphia from 2000-2008. He is black and did not run because of term limits.

${ }^{d}$ Michael Nutter, the victor of the 2007 Philadelphia mayoral election, strongly supported a 'stop-and-frisk' policy. Nutter is black.

${ }^{\mathrm{e}}$ Tom Knox, who is white, spent $\$ 8$ million out of pocket on his bid for the Democratic bid and finished $2^{\text {nd }}$.

${ }^{\mathrm{f}} \mathrm{Al}$ Taubenberger, who is white, mounted a half-hearted campaign as the Republican candidate for mayor, finishing with $17 \%$ of the vote. 
Table 1: Unweighted Sample Descriptives

\begin{tabular}{|c|c|c|c|c|c|}
\hline & M & SD & $\begin{array}{c}\text { \% of } \\
\text { Respondents* }\end{array}$ & $\begin{array}{c}\text { Local } \\
\text { Knowledge } \mathrm{M}^{\#}\end{array}$ & $\begin{array}{c}\text { National } \\
\text { Knowledge } \mathrm{M}^{\#}\end{array}$ \\
\hline \multicolumn{6}{|l|}{ Race $(\mathrm{N}=956)$} \\
\hline Black & - & - & $44 \%[37 \%]$ & $51 \%$ & $43 \%$ \\
\hline White & - & - & $44 \%[52 \%]$ & $58 \%$ & $62 \%$ \\
\hline Other & - & - & $11 \%[11 \%]$ & $40 \%$ & $40 \%$ \\
\hline \multicolumn{6}{|l|}{ Sex $(N=993)$} \\
\hline Female & - & - & $52 \%[55 \%]$ & $51 \%$ & $45 \%$ \\
\hline Male & - & - & $48 \%[45 \%]$ & $54 \%$ & $56 \%$ \\
\hline Age $(N=974)$ & $\begin{array}{c}50.1 \\
{[47.0]}\end{array}$ & $\begin{array}{c}17.1 \\
{[19.4]}\end{array}$ & - & - & - \\
\hline Income $(\mathrm{N}=821)$ & 2.0 & 1.0 & - & - & - \\
\hline $1:<\$ 30,000$ & - & - & $36 \%$ & $41 \%$ & $38 \%$ \\
\hline 2: $\$ 30-60,000$ & - & - & $36 \%$ & $55 \%$ & $50 \%$ \\
\hline 3: $\$ 60,001-\$ 100,000$ & - & - & $16 \%$ & $69 \%$ & $67 \%$ \\
\hline $4:>\$ 100,000$ & - & - & $12 \%$ & $67 \%$ & $77 \%$ \\
\hline Education $(\mathrm{N}=974)$ & $\begin{array}{c}2.9 \\
{[2.6]}\end{array}$ & $\begin{array}{c}1.2 \\
{[1.2]}\end{array}$ & - & - & - \\
\hline 1: < High School & - & - & $9 \%[19 \%]$ & $36 \%$ & $31 \%$ \\
\hline 2: High School Graduate & - & - & $35 \%[35 \%]$ & $47 \%$ & $40 \%$ \\
\hline 3: Some Post-Secondary & - & - & $26 \%[24 \%]$ & $55 \%$ & $51 \%$ \\
\hline 4: College Graduate & - & - & $18 \%[14 \%]$ & $59 \%$ & $62 \%$ \\
\hline 5: > College Graduate & - & - & $13 \%[9 \%]$ & $68 \%$ & $79 \%$ \\
\hline \multicolumn{6}{|c|}{$\begin{array}{l}\text { Figures in brackets are the population parameters of Philadelphia drawn from the } 2007 \text { U.S. American Community } \\
\text { Survey. Income parameters from the ACS are not included here because they were not used in weighting the data (see } \\
\text { Footnote 4). } \\
\text { * Percentages are for valid responses and may not sum to } 100 \% \text { due to rounding. } \\
\text { \# Designates the average percentage of correct responses to the national or local political knowledge items by the } \\
\text { specified group. }\end{array}$} \\
\hline
\end{tabular}


Table 2: OLS Political Knowledge Regressions

\begin{tabular}{|c|c|c|}
\hline & $\begin{array}{l}\text { Local Political } \\
\text { Knowledge }\end{array}$ & $\begin{array}{c}\text { National Political } \\
\text { Knowledge }\end{array}$ \\
\hline & Coefficient & Coefficient \\
\hline \multicolumn{3}{|l|}{ Race } \\
\hline White & - & - \\
\hline Black & $\begin{array}{c}0.022 \\
(0.020)\end{array}$ & $\begin{array}{l}-0.088 * * * \\
(0.021)\end{array}$ \\
\hline Other & $\begin{array}{l}-0.082 * * \\
(0.029)\end{array}$ & $\begin{array}{l}-0.118^{* *} \\
(0.030)\end{array}$ \\
\hline \multicolumn{3}{|l|}{ Gender } \\
\hline Female & - & - \\
\hline Male & $\begin{array}{c}0.020 \\
(0.018)\end{array}$ & $\begin{array}{l}0.096 * * * \\
(0.019)\end{array}$ \\
\hline Age & $\begin{array}{l}0.004^{* * * *} \\
(0.001)\end{array}$ & $\begin{array}{l}0.004 * * * \\
(0.001)\end{array}$ \\
\hline Income & $\begin{array}{l}0.095^{* * * *} \\
(0.011)\end{array}$ & $\begin{array}{l}0.094^{* * *} \\
(0.011)\end{array}$ \\
\hline Education & $\begin{array}{l}0.051^{* * *} \\
(0.008)\end{array}$ & $\begin{array}{l}0.090 * * * \\
(0.009)\end{array}$ \\
\hline Intercept & $\begin{array}{l}-0.027 \\
(0.040)\end{array}$ & $\begin{array}{l}-0.142^{* * *} \\
(0.042)\end{array}$ \\
\hline $\mathrm{R}^{2}$ & 0.254 & 0.369 \\
\hline $\mathrm{N}$ & 815 & 815 \\
\hline
\end{tabular}

Standard errors are in parentheses. 
17 | Local Political Knowledge and Citizen Competence

Table 3: Know-Nothings Logistic Regressions

\begin{tabular}{lccc} 
& Local Know Nothings & National Know Nothings & Cumulative Know Nothings \\
\hline & Coefficient & Coefficient & Coefficient \\
\hline Race & & & - \\
White & - & - & 0.371 \\
Black & $-0.498^{* *}$ & $0.506^{* *}$ & $(0.225)$ \\
& $(0.185)$ & $(0.190)$ & $1.093^{* * *}$ \\
Other & 0.312 & $0.954^{* * *}$ & $(0.293)$ \\
Gender & $(0.255)$ & $(0.266)$ & - \\
$\quad$ Female & - & & -0.256 \\
Male & -0.046 & $-0.584^{* * *}$ & $(0.208)$ \\
& $(0.168)$ & $(0.180)$ & $-0.041^{* * *}$ \\
Age & $-0.031^{* * *}$ & $-0.038^{* * *}$ & $(0.006)$ \\
& $(0.005)$ & $(0.005)$ & $-1.190^{* * *}$ \\
Income & $-0.788^{* * *}$ & $-0.710^{* * *}$ & $(0.174)$ \\
& $(0.113)$ & $(0.117)$ & $-0.721^{* * *}$ \\
Education & $-0.460^{* * *}$ & $-0.634^{* * *}$ & $(0.116)$ \\
& $(0.082)$ & $(0.092)$ & $3.880^{* * *}$ \\
Intercept & $3.559^{* * *}$ & $3.834^{* * *}$ & $(0.508)$ \\
& $(0.408)$ & $(0.433)$ & 613.322 \\
Log likelihood & 870.568 & & .38 \\
Pseudo R-square & .27 & .397 .940 & 229.765 \\
Chi-square & 176.477 & 235.135 & 815 \\
$\mathrm{~N}$ & 815 & 815 & \\
\hline
\end{tabular}

$* \mathrm{p}<.05 * * \mathrm{p}<.01 * * * \mathrm{p}<.001$

Standard errors are in parentheses. 


\section{$\underline{\text { Citations }}$}

Bennett, Stephen Earl. 1988."'Know-Nothings' Revisited: The Meaning of Political Ignorance Today." Social Science Quarterly 69:476-90.

Bennett, Stephen Earl. 1996. "'Know-Nothings' Revisited Again." Political Behavior 18:219-33.

Bennett, Stephen Earl. 1997. "Knowledge of Politics and Sense of Subjective Political Competence.” American Politics Research 25: 230 -240.

Bobo, Lawrence, and Franklin D. Gilliam. 1990. "Race, Sociopolitical Participation, and Black Empowerment." The American Political Science Review 84:377-393.

Converse, Philip E. 1964. “The Nature of Belief Systems in Mass Publics.” In D.E. Apter (Ed.), Ideology and Discontent. New York: Free Press.

Delli Carpini, Michael X., and Scott Keeter. 1996. What Americans Know About Politics and Why it Matters. New Haven, CT: Yale University Press.

Hyman, Herbert H., and Paul B. Sheatsley. 1947. "Some reasons why information campaigns fail." Public Opinion Quarterly 11:412-423.

Krosnick, Jon A. 1990. "Government policy and citizen passion: A study of issue publics in contemporary America." Political Behavior 12:59-92.

Lupia, Arthur. 1994. "Shortcuts versus Encyclopedias: Information and Voting Behavior in California Insurance Reform Elections." American Political Science Review 88:63-76.

Lupia, Arthur. 2006. "How Elitism Undermines the Study of Voter Competence." Critical Review 18:217-232.

Lupia, Arthur, and Jon A. Krosnick. 2008. "Problems with ANES Questions Measuring Political Knowledge." Available at:

http://www.electionstudies.org/announce/newsltr/20080324PoliticalKnowledgeMemo.pd f [Accessed February 24, 2011]

Luskin, Robert C. 1990. “Explaining Political Sophistication.” Political Behavior 12: 331-361.

Macedo, Stephen, and Chris F. Karpowitz. 2006. “The Local Roots of American Inequality.” PS: Political Science and Politics 39:59-64.

Moy, Patricia, Michael R. McCluskey, Kelley McCoy, and Meg A. Spratt. 2004. "Political 
Correlates of Local News Media Use.” Journal of Communication 54:532-546.

Neuman, W. Russell. 1986. The Paradox of Mass Politics: Knowledge and Opinion in the American Electorate. Cambridge, Mass.: Harvard University Press.

Page, Benjamin I., and Robert Y. Shapiro. 1992. The Rational Public: Fifty Years of Trends in American Policy Preferences. Chicago: University of Chicago

Popkin, Samuel. 1993. "Information Shortcuts and the Reasoning Voter." In Information, Participation and Choice, ed. Bernard Grofman. Ann Arbor: University of Michigan Press.

Price, Vincent, and John Zaller. 1993. Who gets the news? Alternative measures of news reception and their implications for research. Public Opinion Quarterly 57:133-164.

Shaker, Lee. 2009. "Citizens' Local Political Knowledge and the Role of Media Access.” Journalism and Mass Communication Quarterly 86: 809.

Sniderman, Paul M., Richard A. Brody, and Philip E. Tetlock. 1991. Reasoning and Choice: Explorations in Political Psychology. Cambridge: Cambridge University Press.

Somin, Ilya. 1998. "Voter Ignorance and the Democratic Ideal." Critical Review 12:413-58.

Somin, Ilya. 2004. "When Ignorance Isn't Bliss: How Political Ignorance Threatens Democracy." Cato Institute Policy Analysis No. 525.

Somin, Ilya. 2006. "Knowledge about ignorance: New directions in the study of political information." Critical Review 18:255-278.

Stein, Benjamin. 1983. "Valley Girls View the World." Public Opinion 6:18-19.

Verba, Sidney, Nancy Burns, and Kay Lehman Schlozman. 1997. "Knowing and Caring about Politics: Gender and Political Engagement.” The Journal of Politics 59: 1051-1072.

Weissberg, Robert. 2001. "Democratic Political Competence: Clearing the Underbrush and a Controversial Proposal." Political Behavior 23:257-84. 